\title{
Možnosti in meje dialoga med judi in kristjani
}

\author{
Prospects and Limits of Dialogue \\ between Jews and Christians
}

Judovsko-krščanski viri in razsežnosti dialoga je delovno področje simpozija o možnostih dialoga med Katoliško cerkvijo in judovstvom ali splošneje med judovstvom in krščanstvom. Simpozij se navezuje na izjavo o razmerju Cerkve do nekrščanskih verstev, Nostra aetate, ki so jo koncilski očetje drugega vatikanskega cerkvenega zbora sprejeli 28. oktobra 1965. Za jude je temeljna teološka osnova razmišljanja o možnostih dialoga Sveto pismo Stare zaveze v obsegu judovskega trodelnega kanona, za kristjane pa Sveto pismo Stare in Nove zaveze. Dialoško razmerje v zgodovini judovstva nikoli ni bilo samoumevno. Že preroki Stare zaveze izredno pogosto bičajo nezvestobo svojega ljudstva do Boga, Jezus v stikih s »farizeji« kritiko starozaveznih prerokov samo še zaostri, kristjani pa so skozi dva tisoč let odnos do judov presojali pod vplivom svetopisemske kritike nezvestobe in trdosrčnosti »Jezusovih morilcev«. Vzklikanje judov »Križaj ga!«, kot poročajo evangeliji v zvezi z Jezusovo obsodbo pred Pilatom, je skozi vso zgodovino vplivalo na odnose med judi in kristjani.

Onkraj krize dialoga med judi in kristjani pa odkrivamo globljo krizo odnosov med Bogom in človekom, ki se kaže v poročilih o stvarjenju Adama in Eve in v zgodbi o Kajnu in Abelu. Apostol Pavel je v svojih pismih, zlasti v Pismu Rimljanom, poglobljeno razložil nasprotje med človekovo zasidranostjo v grehu in brezpogojno milostjo Božjega odrešenja. S tem 
je zavrnil vsak poskus utemeljevanja človekove samoodrešitve na ravni humanizma. Bog judov ni izbral za izvoljeno ljudstvo zaradi moralnih prednosti pred drugimi ljudstvi, ampak zato, ker so bili najšibkejši in torej najbolj potrebni Božje milosti. Ko razmišljamo o možnosti dialoga med judi in kristjani ter sploh dialoga med ljudmi, se odločamo med »humanistično " vizijo dialoga in med dialogom z navdihom vere v Boga, ki je onkraj dobrega in zlega in s svojo suverenostjo vse ljudi rešuje krivde in smrti. V luči vere v Boga Svetega pisma, ki je eden, svet in vsemogočen, obstaja možnost dialoga, ki ga ne moremo meriti s humanističnimi in družbenimi merili. Enost Boga omogoča edinost vesoljnega človeštva, tudi ko se vse okrog nas ruši zaradi gospodarskih, političnih in zdravstvenih zlomov - morda najbolj takrat.

Prva značilnost dialoga, ki ga vzpostavlja Bog med ljudmi, je konflikt. Preroki so od izvoljenega ljudstva zahtevali spoznanje in zvestobo. Zagovarjali so resnico, da ista Božja merila morale veljajo brezpogojno enako za faraone, cesarje in njihove sužnje. Na tej osnovi je možen resničen dialog, na drugih osnovah se pase iluzija. Ko je Mojzes po Božjem naročilu stopil pred faraona, je od njega moral zahtevati brezpogojno pokorščino Bogu vsega stvarstva. Ko so nadloge zlomile faraonovo samovoljo, je sledil izhod iz egiptovske sužnosti, ki je kmalu dobil tipološki pomen izhoda iz vseh vrst zemeljske sužnosti, izhoda iz krivde in izhoda iz smrti, kot je razvidno iz vsebin krščanskega praznika velike noči.

Enost Boga stvarnika, ki brezpogojno rešuje človeka, omogoča edinost svetopisemske odrešenjske zgodovine $\mathrm{v}$ razponu med začetkom in koncem, znotraj te zgodovine pa stalno napetost med obljubo in izpolnitvijo. Ta napetost določa možnosti in meje dialoga med Bogom in človekom, interakcijo med Staro in Novo zavezo in končno možnosti ter meje dialoga med ljudmi. Bog nastopa kot Beseda, ki ni abstrakten koncept v sistemu razpravljanja o razmerju med fizikalnim vzrokom in učinkom, temveč učlovečena beseda Božja osebe, ki stopa v samo središče človeške osebe.

Svetopisemska resnica o Bogu razodetja in o človeku predstavlja stalno preizkušnjo za vsako vrsto interpretacije Svetega pisma. Bog razodetja je osebni Bog, zato naš dialog v razmerju do Boga lahko poteka v moči intuicije in mističnega doživljanja Božje bližine. Ko dojemanje Boga na osebni ravni, ki poteka brez besed, prehaja v verbalni dialog, ki ga 
določa jezik s svojimi besedami in slovničnimi oblikami, se začenja »kulturna« kriza dialoga. Ko poskušamo vsebine temeljnega besedišča in temeljnih literarnih oblik Svetega pisma ustrezno prevesti v svoj jezik, smo v težavah, ker so temeljne vsebine Svetega pisma tako izrazito duhovne narave, da jih jezikovna znamenja ne morejo ustrezno zajeti.

To stanje je razlog, da se je v zgodovini interpretacije Svetega pisma tako v judovstvu kot v krščanstvu razvilo razlikovanje med dobesednim in raznimi duhovnimi pomeni jezikovnih znamenj. Pisci svetih besedil pa so si pomagali s celostno poetično govorico, ki je sposobna nakazati pomen, širši in globlji od tistega, ki ga izražajo posamezna jezikovna znamenja. Že antični prevodi Svetega pisma pričajo, da so prevajalci Svetega pisma v indoevropske jezike nekatere temeljne hebrejske besede prevajali z več izrazi svojega jezika. V grški Septuaginti in latinski Vulgati so nastala širša semantična polja, ki so z večjim obsegom besedišča izrazila širok pomen temeljnega hebrejskega besedišča.

Zaradi občutnih premikov v pomenskih poudarkih v grškem prevodu Svetega pisma judje Septuaginti nikoli niso pripisovali enake avtoritete kot izvirnemu hebrejskemu besedilu. Že dva tisoč let se pri vrednotenju hebrejskega izvirnika in prevodov izvirnika v druge jezike kažejo meje možnosti teološkega dialoga med judi in kristjani. Še bolj pa se kažejo na področju razlage Svetega pisma Nove zaveze. Judje na splošno zavračajo sistemski pristop krščanske teologije, ker so sami bolj vsestransko ohranili tradicijo zgodb kot temeljnega sredstva posredovanja svetopisemskih zgodb. Zato je judovska zgodovina interpretacije Svetega pisma tudi bolj odprta za prepoznavanje večpomenskosti temeljnega besedišča Svetega pisma. Judovski razlagalci radi poudarjajo pluralnost v judovski interpretaciji Svetega pisma do mere, ko pogosto ni več gotovo, ali pri tem dopuščajo prava nasprotja $\mathrm{v}$ razlagah ali le komplementarne razlike. Z obratom sodobne strokovne eksegeze iz prevlade zgodovinske kritike v literarno kritiko pa so se možnosti dialoga med judovskimi in krščanskimi razlagalci Svetega pisma povečale. Dialog med judovskimi in krščanskimi izvedenci Svetega pisma Stare zaveze je v moderni dobi že kar samoumevno dejstvo.

Toliko bolj so judje pozorni na pristop krščanske razlage Nove zaveze v razmerju do Stare zaveze v primerih besedil, ki prikazujejo jude kot 
nasprotnike Jezusovega evangelija. Dejstvo je namreč, da so se zagovorniki antisemitizma skozi dva tisoč let pogosto sklicevali na negativno podobo judov v Novi zavezi. Zato dokument Nostra Aetate ne izpostavlja takih mest, temveč najbolj temeljne skupne točke vere v enega Boga stvarnika in odrešenika. Nov dialoški pristop je izziv za razlago razmerja med Staro zavezo kot obljubo in Novo zavezo kot izpolnitvijo. Iskanje globlje razlage razmerja med obljubo in izpolnitvijo povečuje možnosti dialoga z judi, ker to razmerje najbolj vsestransko kaže na kontinuiteto odrešenjske zgodovine, na primarno vlogo Božje milosti v Svetem pismu in na osrednji pomen Božjega dela odpuščanja in sprave v judovstvu in krščanstvu.

Poglobljena razlaga edinosti med Staro in Novo zavezo pa je vsestransko kompleksno vprašanje. Ključnega pomena je ugotovitev, da so knjige Stare zaveze knjige stalnega pričakovanja. Druga pomembna ugotovitev je, da zgodovina nastajanja knjig Stare zaveze kaže na nove razlage starih izročil o Božjem razodetju, to pa je osnova za tipološko razmerje med starimi in novimi izročili. Izhod iz Egipta pomeni tip za dojemanje poznejših izhodov iz situacije stiske: izhod iz raznih oblik suženjstva, med drugim izhod iz krivde in smrti. Te značilnosti starozaveznih besedil omogočajo proces aktualizacije starozaveznih besedil $v$ novih situacijah, predvsem pa pot poglabljanja in širitve duhovne razlage starozaveznih tipoloških razmerij v odnosu do Nove zaveze. Razlaga razmerja med Staro in Novo zavezo pa v zgodovinskem razvoju človeštva ne pomeni samo razlage Nove zaveze v luči Stare zaveze, temveč tudi razlago Stare zaveze v luči Nove zaveze. To je bila značilna pot prve Cerkve, kot je razvidno predvsem iz Apostolskih del in iz Pavlovih pisem.

Vera v Božje razodetje omogoča osvobajanje vseh pred »črko«, ki ubija, z milostjo Božjega razsvetljenja. Odprtost za dialog omogoča tako judom kot kristjanom obojestransko plemenitenje spoznanja o Bogu in človeku, o problemu zla in o veselem sporočilu Božjega razodetja, ki se bo končalo ob izpolnitvi obljube o dopolnitvi stvarstva. Ko vera pomeni zaupanje v Božjo navzočnost v našem svetu, ostane živo upanje v razvoj dialoga med vsemi verujočimi. S tem pa se zmanjšuje nevarnost pasti slepega zaupanja družbenim modelom, ki sestavljajo okvir lokalne in globalne zemeljske domovine. 
Vse, kar so avtorji prispevkov tega simpozija razkrili v svojih analizah cerkvenih dokumentov, zgodovine v odnosu do judov in literarnih pristopov v prikazih judov v življenjskih okoliščinah, nam lajša pot do »tujcev«, da jih doživimo kot sosede $\mathrm{v}$ dojemanju veselega oznanila $\mathrm{v}$ razponu med obljubo in izpolnitvijo. 


\section{Posebna številka revije Edinost in dialog $76(2021) 1$}

Special issue of Unity and Dialogue 76 (2021) 1

\section{Judovsko-krščanski viri in razsežnosti dialoga}

Jewish-Christian Sources and

Dimensions of Dialogue

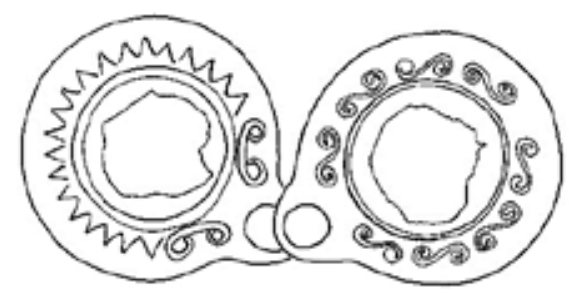

